\title{
A Frequency Statistics Research of Phoneme and Phoneme Constitutions in Hefei Dialect
}

\author{
Yonghong $\mathrm{Li}^{\mathrm{a}}$ \\ Key Lab of China's National Linguistic Information Technology of Ministry of Education, Northwest \\ University for Nationalities, Lanzhou 730000, China \\ ayhweiwei@126.com
}

Keywords: Phoneme, Hefei, Dialect, frequency.

\begin{abstract}
This template explains and demonstrates how to prepare your camera-ready paper for Trans Tech Publications. The best is to read these instructions and follow the outline of this text. Please make the page settings of your word processor to A4 format ( $21 \times 29,7 \mathrm{~cm}$ or 8 x 11 inches); with the margins: bottom $1.5 \mathrm{~cm}$ (0.59 in) and top $2.5 \mathrm{~cm}$ (0.98 in), right/left margins must be $2 \mathrm{~cm}$ (0.78 in). This template explains and demonstrates how to prepare your camera-ready paper for Trans Tech Publications. The best is to read these instructions and follow the outline of this text. Please make the page settings of your word processor to A4 format ( $21 \times 29,7 \mathrm{~cm}$ or $8 \times 11$ inches); with the margins: bottom $1.5 \mathrm{~cm}$ (0.59 in) and top $2.5 \mathrm{~cm}$ (0.98 in), right/left margins must be $2 \mathrm{~cm}(0.78 \mathrm{in})$.
\end{abstract}

\section{Introduction}

Phoneme is a smallest phonetic unit which can distinguish the meaning of word in the language system. Different languages have different number and type of phonemes. Sino-tibetan languages are all syllable ways with single character and tone, initials, finals and tones as three main factors of phonemic system. One language is more than 100 phonemes, or less than 20-30 phonemes, the frequency, function and position of each phoneme are different in the language. Hefei dialect belongs to the Jianghuai mandarin language Hongchao dialects, from the point of listening and intonation, Hefei dialect is a typical mixed accent, tone is hard. Hefei dialect with tone features of north generosity, also have the south obscure pronunciation and words system, at the same time; it also retains a considerable number of ancient Chinese pronunciation and vocabulary based on the modern Chinese. Hefei dialect retains entering tones, which as the representative of the Jianghuai mandarin language. Previous research of Hefei dialect is mainly concentrated on the phonemic induction, difference evolution. 'The liaison and modified tone of Hefei dialect and the optimization theory analysis of trisyllabic sequences neutral tone', using the method of experimental phonetics and the latest theory of phonology are used to make description and phonetic system analysis on the two phenomena, a unified interpretation with principle has obtained. Results show that marked constraint conditions "lower tone" is applicable to continuous modified tone and suitable for phonetic system analysis of trisyllabic sequences neutral tone, therefore there is close relation between the two[1]. 'Ni Lai initial are read [z] initials in the Hefei dialect phenomenon research" think Ni Lai initial today read [z] initials are resulted from high vowel in Hefei dialect [2]. Statistics and functional studies of phonemic frequency is less, Mandarin Chinese, Beijing dialect, and sporadic minority languages have some statistical analysis of phoneme [3][4]. We use "Chinese dialect vocabulary" edited Chinese language \&literature linguistics of Peking University as corpus, the frequency of Hefei dialect initials, finals and tones are calculated, and the initials, combined types initials, finals and tones are made frequency statistics. The syllable distribution of Hefei dialect, syllable combined type and tone status questions are discussed. 


\section{Frequency Statistics of Phonemic System}

There are 21 initials, 41 finals and 5 tones in the Hefei dialect system, occurrence frequency of initials, finals and tones are made statistics of Hefei dialect in 3000 words.

\subsection{Statistics of Homophones}

Hefei dialects 3000 words are corresponding to 941 syllables; the number of homophone of each syllable is 3.19. The most syllables of homophone is [ $\mathrm{t}^{\mathrm{h}}{ }^{\mathrm{h}} 1$ rising tone], 22 homophone "䧳、瓷、慈、 磁磁石、辞、词、祠、堤、题、提、啼、蹄、齐、脐、奇奇怪、骑骑马、祁、鯺、其、旗、 棋、麒". [t5153] and [\$153] have 21 homophones, there are 313 syllables without homophone, accountings for $10.4 \%$ of the total number of syllables, 194 syllables have two homophone.

\subsection{The Frequency Statistics of Initials}

The initials of Hefei dialects are simpler from the type, but all have distribution in the pronunciation parts and methods, nasal and lateral voice type are especially simple, [n/l] discernable phenomenon exists. Hefei dialect with 22 initials, the average frequency is 142.9. From the place of articulation, the highest frequency was blade-palatal, it accounts for $17.2 \%$ of the total frequency of initials, the second are dorsal and blade-alveolar, it accounts for $16.4 \%$ and $15.6 \%$ of the total frequency, respectively, the lowest occurrence frequency is labiodental, it accounts for 3.3\%; The articulation place of initials are relatively complete in Hefei dialect, and frequency distribution is relatively balanced, difference is not obvious. From the point of articulation manner, the highest frequency was affricate, it accounts for $29.1 \%$ of the total frequency, the second are fricative and plosive, it accounts for $24 \%$ and $23.6 \%$, and the lowest occurrence frequency is nasal sound, it accounts for only $3.8 \%$ of the total frequency. From a single initials, except for the zero initial, the highest occurrence frequency is lateral apical [1], it accounts for $7.17 \%$ of the total frequency, the second is blade-palatal voiceless affricate [ts], it accounts for $6.4 \%$ of the total frequency, the lowest occurrence frequency is blade-palatal voiced affricate [z], it accounts for $2.23 \%$ of the total frequency, the initial frequency are shown in Table 1.

\begin{tabular}{|c|c|c|c|c|c|c|c|c|c|c|c|}
\hline $\begin{array}{c}\text { order } \\
\text { number }\end{array}$ & $\begin{array}{c}\text { initia } \\
1\end{array}$ & $\begin{array}{c}\text { frequenc } \\
\mathrm{y}\end{array}$ & $\begin{array}{c}\text { order } \\
\text { number }\end{array}$ & $\begin{array}{c}\text { initia } \\
\mathrm{l}\end{array}$ & $\begin{array}{c}\text { frequenc } \\
\mathrm{y}\end{array}$ & $\begin{array}{c}\text { order } \\
\text { number }\end{array}$ & $\begin{array}{c}\text { initia } \\
1\end{array}$ & $\begin{array}{c}\text { frequenc } \\
\mathrm{y}\end{array}$ & $\begin{array}{c}\text { order } \\
\text { number }\end{array}$ & $\begin{array}{c}\text { initia } \\
1\end{array}$ & $\begin{array}{c}\text { frequenc } \\
\mathrm{y}\end{array}$ \\
\hline 1 & $\$$ & 372 & 7 & $\mathrm{p}$ & 141 & 13 & $\mathrm{t}^{\mathrm{h}}$ & 116 & 19 & $\mathrm{f}$ & 98 \\
\hline 2 & l & 215 & 8 & $\mathrm{t}$ & 137 & 14 & $\mathrm{~m}$ & 113 & 20 & $\mathrm{k}^{\mathrm{h}}$ & 80 \\
\hline 3 & to & 213 & 9 & $\mathrm{k}$ & 134 & 15 & $t^{h}$ & 112 & 21 & $z_{\text {c }}$ & 67 \\
\hline 4 & tş & 192 & 10 & $\mathrm{~S}$ & 130 & 16 & $\mathrm{~s}$ & 112 & & & \\
\hline 5 & 6 & 168 & 11 & $\mathrm{ts}^{\mathrm{h}}$ & 127 & 17 & $t^{\mathrm{h}}$ & 111 & & & \\
\hline 6 & $\mathrm{x}$ & 146 & 12 & ts & 117 & 18 & $\mathrm{p}^{\mathrm{h}}$ & 99 & & & \\
\hline
\end{tabular}

\subsection{The Frequency Statistics of Final}

There are 41 finals in Hefei dialect, the highest frequency of monophthong finals up to 1541, which exceed $1 / 2$ of the frequency of total finals, the second is compound vowel finals 889 , it accounts for $29.6 \%$ of the total frequency, the lowest frequency of tail vowel and final of nasal sound is 570 , it accounts for $19 \%$. The types of tail vowel and final of nasal sound are abundant, [ə] and [i] as finals of the essential vowel in a compound vowel, they have very good corresponding relation in $[\mathrm{n}]$ and $[\mathrm{y}]$. From the four breath characteristics of finals, the highest occurrence frequency is opening mouth, it accounts for about half of the total frequency of finals, and the second is the equal-toothed breath, it accounts for $25.6 \%$ of the frequency, the lowest frequency is rhymes containing a rounded front vowel, it accounts for only $6.73 \%$ of the total frequency; The proportion of frequency distribution is disparity in the four breath, the difference is obvious. Finals [1] occurs 197, it accounts for $6.6 \%$ of the total frequency of finals, and frequency of finals are shown in Table 2: 
Table 2 Finals frequency in Hefei dialects

\begin{tabular}{|c|c|c|c|c|c|c|c|c|c|c|c|}
\hline $\begin{array}{c}\text { order } \\
\text { number }\end{array}$ & $\begin{array}{c}\text { fina } \\
1\end{array}$ & $\begin{array}{c}\text { frequenc } \\
\mathrm{y}\end{array}$ & $\begin{array}{c}\text { order } \\
\text { number }\end{array}$ & $\begin{array}{c}\text { fina } \\
1\end{array}$ & $\begin{array}{c}\text { frequenc } \\
\mathrm{y}\end{array}$ & $\begin{array}{c}\text { order } \\
\text { number }\end{array}$ & $\begin{array}{c}\text { fina } \\
1\end{array}$ & $\begin{array}{c}\text { frequenc } \\
\mathrm{y}\end{array}$ & $\begin{array}{c}\text { order } \\
\text { number }\end{array}$ & $\begin{array}{c}\text { fina } \\
1\end{array}$ & $\begin{array}{c}\text { frequenc } \\
\mathrm{y}\end{array}$ \\
\hline 1 & 1 & 197 & 12 & is & 95 & 23 & ie? & 56 & 34 & уə? & 22 \\
\hline 2 & in & 186 & 13 & e & 85 & 24 & 2 & 49 & 35 & in & 21 \\
\hline 3 & ən & 165 & 14 & E & 81 & 25 & ue? & 47 & 36 & ua & 18 \\
\hline 4 & $\mathrm{u}$ & 163 & 15 & u & 79 & 26 & ว? & 46 & 37 & UE & 16 \\
\hline 5 & $\tilde{æ}$ & 158 & 16 & ue & 78 & 27 & yĩ & 45 & 38 & i & 15 \\
\hline 6 & iĩ & 151 & 17 & iə? & 77 & 28 & uã & 42 & 39 & ũ̃ & 13 \\
\hline 7 & əท & 137 & 18 & $\mathrm{y}$ & 73 & 29 & a & 39 & 40 & iE & 13 \\
\hline 8 & 0 & 125 & 19 & $\tilde{U}$ & 70 & 30 & uən & 33 & 41 & ye & 1 \\
\hline 9 & e? & 125 & 20 & iã & 69 & 31 & ye? & 33 & & & \\
\hline 10 & $\tilde{\mathrm{a}}$ & 109 & 21 & iut & 58 & 32 & yn & 28 & & & \\
\hline 11 & v & 98 & 22 & แə? & 57 & 33 & ia & 27 & & & \\
\hline
\end{tabular}

\subsection{The Frequency Statistics of Tone}

Frequency statistics of Hefei four tones are carried out, the highest frequency is falling tone, high and level tone are close to rising tone, the lowest frequency is falling-rising tone and entering tone, the frequency is closer, the statistics of tone frequency as shown in the Table 3.

Table 3 Tone frequency statistics in Hefei dialect

\begin{tabular}{ccccccc}
\hline tone kind & ring method & $\begin{array}{c}\text { Vertical mark } \\
\text { method }\end{array}$ & tone pitch & frequency & ratio(\%) & example \\
falling tone & $\square$ & $\square$ & 53 & 832 & 27.7 & 快 \\
high tone & $\square \square$ & $\square$ & 212 & 616 & 20.5 & 高 \\
rising tone & $\square \square$ & 1 & 55 & 586 & 19.5 & 唐 \\
falling-risin & $\square \square$ & $\square$ & 24 & 503 & 16.8 & 胆 \\
g tone & $\square$ & 1 & 4 & 463 & 15.4 & 急 \\
entering tone & $\square$ & $\square$ &
\end{tabular}

\section{The Combination of Phoneme}

The sound-rhyme, sound-tone and rhyme-tone of Hefei dialect, and frequency of these three phoneme combination are made calculation and analysis.

\subsection{The Sound-rhyme Combination}

The phonology combination number 41 initials and 21 finals are 387 in Hefei dialect, the sound-rhyme combination of the average frequency is 7.8. The highest frequent [to I] appear in 44 syllables; and only one sound-rhyme combination includes [kin], [fo], [sa], [k $\mathrm{k}^{\mathrm{h}} \tilde{\mathrm{w}}$ ] 35 etc. The combination frequencies of sound-rhyme are in descending order, first 20 sound-rhyme combination as shown in Table 4.

Table 4 Sound-rhyme combination frequency in Hefei dialect

\begin{tabular}{|c|c|c|c|c|c|c|c|c|c|c|c|}
\hline number & sound-rhyme & frequency & number & sound-rhyme & frequency & number & sound-rhyme & frequency & number & sound-rhyme & frequency \\
\hline 1 & $\$ 1$ & 52 & 6 & tciĩ & 33 & 11 & $\$ y$ & 25 & 16 & $\mathrm{tg}^{\mathrm{h}}$ in & 21 \\
\hline 2 & $\mathrm{ts}^{\mathrm{h}} 7$ & 45 & 7 & \$in & 32 & 12 & tş & 24 & 17 & xue & 20 \\
\hline 3 & ts? & 44 & 8 & \$ĩ̃ & 29 & 13 & $\sin$ & 23 & 18 & sən & 20 \\
\hline 4 & tein & 39 & 9 & \$ue & 27 & 14 & fu & 22 & 19 & $t^{t} \mathrm{~h}^{\mathrm{h}} \mathrm{i}$ & 19 \\
\hline 5 & $\mathrm{~s}_{1}$ & 33 & 10 & tşən & 25 & 15 & tcio & 22 & 20 & $\mathrm{ts}^{\mathrm{h}}$ ən & 19 \\
\hline
\end{tabular}

\subsection{The Sound-tone Combination}

The combination number of 21 initials and 5 tones are 101 in Hefei dialect, except the initials [k], [ts], [t], and [t6] don't collocate 55 rising tone, the rest of the 17 initials can and collocate [high and level tone 212], [rising tone 55], [falling-rising tone 24], [falling tone 53], entering tone 4 rules collocation, that is to say, Hefei 3000 syllables combination, there is no initial [k55], [ts55], [t55] and [t6 55] collocation 4 kinds of circumstances. The highest occurrence frequency [\$55] appears in 119 syllables. Tone combination frequencies are in descending order, the first 20 combination tone as shown in Table 5. 
Table 5 Frequency of sound-tone combination in Hefei dialect

\begin{tabular}{|c|c|c|c|c|c|c|c|c|c|c|c|}
\hline number & sound-tone & frequency & number & sound-tone & frequency & number & sound-tone & frequency & number & sound-tone & frequency \\
\hline 1 & \$ rising tone & 119 & 6 & $\begin{array}{l}\text { ts falling } \\
\text { tone }\end{array}$ & 67 & 11 & $\begin{array}{l}\mathrm{ts}^{\mathrm{h}} \text { rising } \\
\text { tone }\end{array}$ & 54 & 16 & $\begin{array}{l}6 \text { falling } \\
\text { tone }\end{array}$ & 48 \\
\hline 2 & $\$$ falling tone & 91 & 7 & $\mathrm{t}$ falling tone & 64 & 12 & $\mathrm{x}$ rising tone & 52 & 17 & $\begin{array}{l}\text { ts falling } \\
\text { tone }\end{array}$ & 47 \\
\hline 3 & 1 rising tone & 86 & 8 & $\begin{array}{l}\text { tc high level } \\
\text { tone }\end{array}$ & 63 & 13 & $\begin{array}{l}\text { \$ high level } \\
\text { tone }\end{array}$ & 52 & 18 & $\begin{array}{l}6 \text { high level } \\
\text { tone }\end{array}$ & 46 \\
\hline 4 & to falling tone & 73 & 9 & $\begin{array}{c}\mathrm{p} \text { falling } \\
\text { tone }\end{array}$ & 58 & 14 & $\begin{array}{c}\text { K high level } \\
\text { tone }\end{array}$ & 50 & 19 & $\begin{array}{c}\mathrm{X} \text { falling } \\
\text { tone }\end{array}$ & 45 \\
\hline 5 & $\begin{array}{l}\text { \$ falling-rising } \\
\text { tone }\end{array}$ & 68 & 10 & $\begin{array}{l}\text { tş high level } \\
\text { tone }\end{array}$ & 57 & 15 & $\mathrm{t}^{\mathrm{h}}$ rising tone & 48 & 20 & $\begin{array}{l}\text { l entering } \\
\text { sound }\end{array}$ & 44 \\
\hline
\end{tabular}

\subsection{Rhyme-tone Combination}

The combination relationship of initials and finals in 3000 syllable in Hefei dialect, the combination number of 39 finals and 5 tones is 137 in Hefei dialect. Finals [ฉ?], [ə P], [iฉ?], [Iə?], [ur?], [ye?], [ye?], [yə?], [ye] can only collocate entering sound 4, but cannot collocate high and level tone 212 , rising tone 55 , falling-rising tone 24 , falling tone 53; except the finals [p?], [ə९], [Iฉ?], [Iə२], [ue?], [ye?], [ye?], [yə?], [ye], the remaining 30 finals cannot collocate entering sound 4, but they are fully able to collocate high and level tone 212, rising tone 55, falling-rising tone 24, falling tone 53. [ $\mathrm{B}$ ? entering tone] the highest frequency appears in 125 syllables. Rhyme-tone combination frequencies are in descending order; the first 20 rhyme-tone combination as shown in Table 6.

Table 6 Rhyme-tone combination frequency in Hefei dialect

\begin{tabular}{|c|c|c|c|c|c|c|c|c|c|c|c|}
\hline number & rhyme-tone & frequency & number & rhyme-tone & frequency & number & rhyme-tone & frequency & number & rhyme-tone & frequency \\
\hline 1 & $\begin{array}{l}\mathrm{e} \text { ? entering } \\
\text { tone }\end{array}$ & 125 & 6 & $\begin{array}{l}\text { ic? entering } \\
\text { tone }\end{array}$ & 56 & 11 & iĩ falling tone & 52 & 16 & 1 rising tone & 46 \\
\hline 2 & $\begin{array}{l}\text { iə? entering } \\
\text { tone }\end{array}$ & 77 & 7 & $\begin{array}{l}\text { in high level } \\
\text { tone }\end{array}$ & 56 & 12 & $\begin{array}{l}\text { ue? entering } \\
\text { tone }\end{array}$ & 47 & 17 & $\begin{array}{l}\text { əy high level } \\
\text { tone }\end{array}$ & 45 \\
\hline 3 & I falling tone & 75 & 8 & in rising tone & 56 & 13 & $\begin{array}{l}\text { u falling-rising } \\
\text { tone }\end{array}$ & 47 & 18 & o falling tone & 43 \\
\hline 4 & $\mathrm{u}$ falling tone & 58 & 9 & $\begin{array}{l}\text { on high level } \\
\text { tone }\end{array}$ & 54 & 14 & on falling tone & 47 & 19 & $\tilde{æ}$ rising tone & 41 \\
\hline 5 & $\begin{array}{l}\text { uə? entering } \\
\text { tone }\end{array}$ & 57 & 10 & $\begin{array}{l}\tilde{x} \text { falling } \\
\text { tone }\end{array}$ & 53 & 15 & ə? entering tone & 46 & 20 & e falling tone & 40 \\
\hline
\end{tabular}

\section{Conclusion}

The phoneme of 3000 morpheme and phonological combination frequency are made statistics in Hefei dialect, the status of phoneme and phonological combination in in language system are sorted, phonological function are made quantitative research, the function pattern of the phoneme is obtained in the structure, the research results provides the basic data for function of phoneme in in the language system further.

\section{Acknowledgements}

National Social and scientific Fund Major Projects (10\&ZD125)

\section{References}

[1].Kong Huifang, An Optimality Theoretic analysis of tone sandhi and neutral tones in trisyllabic sequence in hefei dialect, ,Journal of Anhui Agricultural University . Vol. 13 (2004) No. 3, p. 120-123.

[2].SUN Yizhi, Probing into the fact that the initial groups of ni and lai are pronounced as/z/in Hefei dialect, Studies of the Chinese Language. (2007) No. 1, p. 55-60.

[3].Li Yonghong, Fang Huaping. Distribution of the phonetic system and statistical studies for beijing dialect, 2011 International Conference on Social Sciences and Society. (2011) 247-253.

[4].Su Xinchun, Lin Jinzhan, Statistic analysis of syllables and character-load function of chinese putonghua --- based on the contemporary chinese dictionary, Chinese Languages.3 (2006) 274-284. [5].The department of Chinese languages and literature and the division of language teaching of Beijing University, Characters Collection of Chinese Dialects, second ed., Languages Press, China, 2003. 